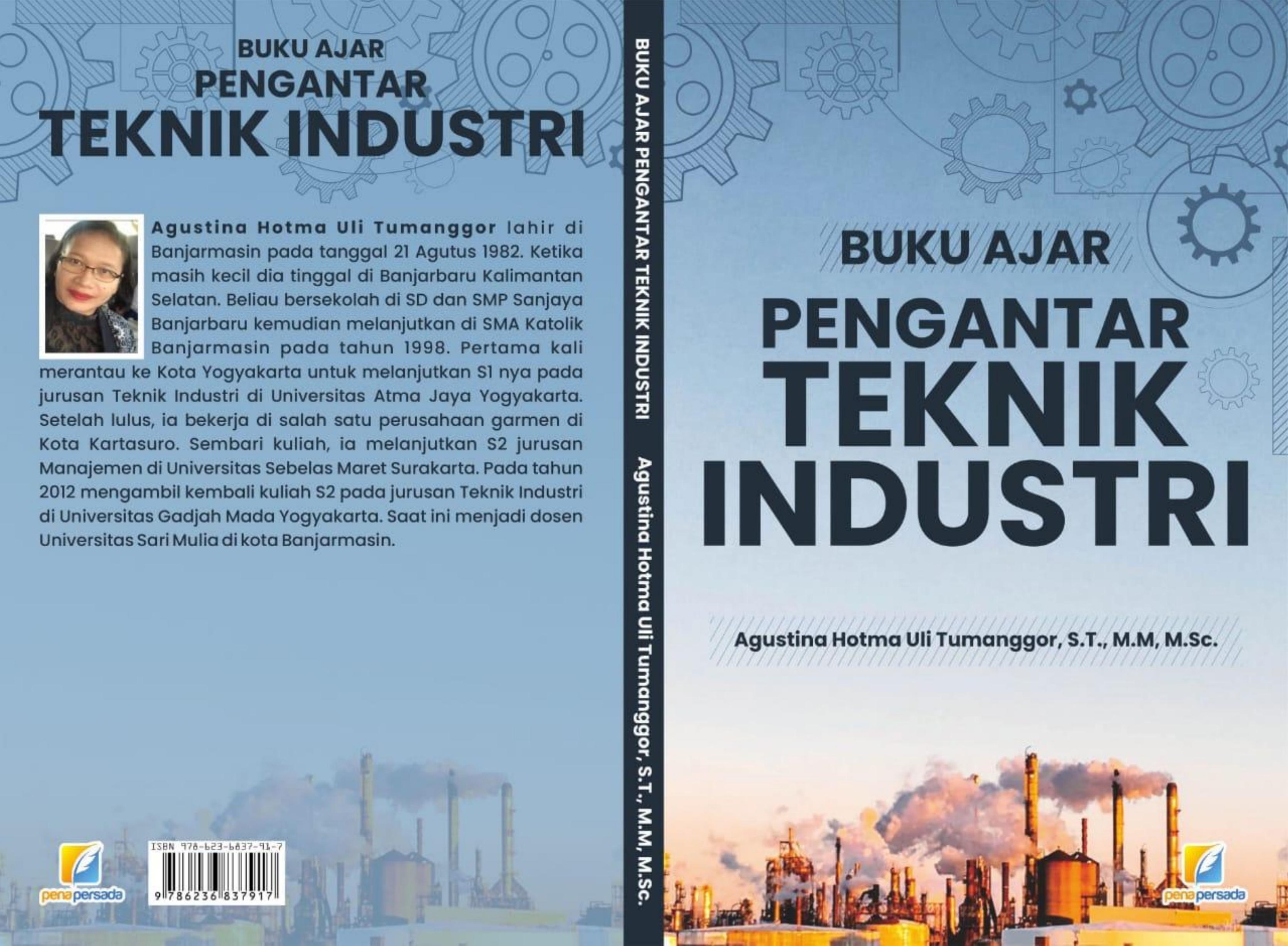




\section{BUKU AJAR \\ PENGANTAR TEKNIK INDUSTRI}

Agustina Hotma Uli Tumanggor, S.T., M.M, M.Sc.

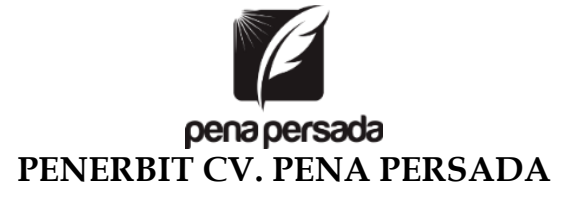




\title{
BUKU AJAR \\ PENGANTAR TEKNIK INDUSTRI
}

\author{
Penulis: \\ Agustina Hotma Uli Tumanggor, S.T., M.M, M.Sc. \\ ISBN : 978-623-6837-91-7 \\ Design Cover : \\ Retnani Nur Briliant \\ Layout : \\ Nisa Falahia \\ Penerbit CV. Pena Persada \\ Redaksi : \\ Jl. Gerilya No. 292 Purwokerto Selatan, Kab. Banyumas \\ Jawa Tengah \\ Email : penerbit.penapersada@gmail.com \\ Website : penapersada.com Phone : (0281) 7771388 \\ Anggota IKAPI \\ All right reserved \\ Cetakan pertama : 2020
}

Hak Cipta dilindungi oleh undang-undang. Dilarang memperbanyak karya tulis ini dalam bentuk apapun tanpa izin penerbit 


\section{KATA PENGANTAR}

Puji dan syukur kami panjatkan kehadirat Tuhan Yang Maha Esa, atas limpahan berkah dan rahmat-NYa Modul Pembelajaran Mata Kuliah Pengantar Teknik Industri dapat diselesaikan. Dengan adanya modul ini diharapkan dapat menambah pengertian dan meningkatkan pengetahuan mahasiswa dalam mempelajari Mata Kuliah Pengantar Teknik Industri.

Tak ada gading yang tak retak, modul ini masih perlu perbaikan untuk memajukan ilmu pengetahuan dan teknologi.

Banjarmasin

Penulis 


\section{DAFTAR ISI}

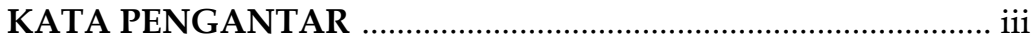

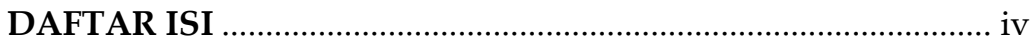

SEJARAH KEILMUAN TEKNIK INDUSTRI ............................ 1

A. Profesi Teknik Industri Lahir ........................................... 1

B. Era Perkembangan teknik Industri ..................................... 4

RUANG LINGKUP KEILMUAN TEKNIK INDUSTRI ............. 9

A. Pengertian Teknik (Engineering) ....................................... 9

B. Pengertian Science .............................................................. 10

C. Karakteristik Dasar Engineering ......................................... 11

D. Ruang Lingkup Teknik Industri ....................................... 14

KOMPONEN SISTEM YANG MEMBANGUN TEKNIK

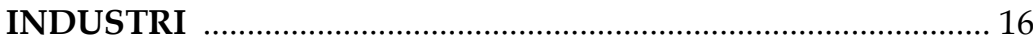

A. Komponen Sistem Terintegrasi Teknik Industri ........... 16

B. Kinerja dan Aktivitas Teknik Industri ............................ 18

STRUKTUR KURIKULUM TEKNIK INDUSTRI ...................... 20

A. Struktur Kurikulum Teknik Industri ................................ 20

B. Ruang Lingkup Teknik Industri ......................................... 25

PERAN PEREKAYASA INDUSTRI DI MANUFAKTUR DAN

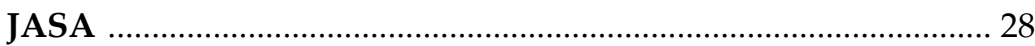

A. Latar Belakang ….......................................................... 28

B. Management Rekayasa (Engineering Management) ........ 29

C. Industrial Engineering and Engineering Management ........30

D. Siklus Pengembangan Teknologi ....................................... 32

E. Disiplin Manajemen Rekayasa ............................................ 36

PERKEMBANGAN KEILMUAN TEKNIK INDUSTRI ............. 38

A. Revolusi Industri ......................................................... 38

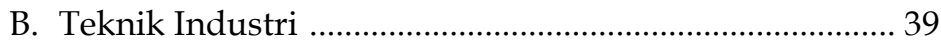

C. Kronologi Perkembangan Keilmuan Teknik

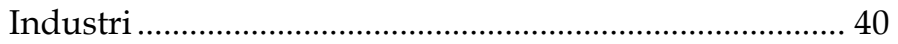

PROFESIONALISME DAN ETIKA REKAYASA ........................ 44

A. Pengertian profesi dan Profesionalisme .......................... 44

B. Pengertian Profesionalisme ............................................... 45

C. Pengertian Kode Etika........................................................ 46

D. Peran dan etika Profesi dalam Bidang Teknik

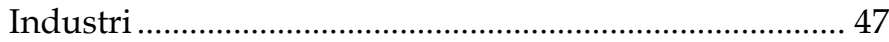


A. Konsep Teknik Industri .................................................. 49

B. Profesi Teknik Industri .................................................... 51

C. Etika Profesi dalam Engineering ……………….............. 52

D. Peran Etika Profesi ......................................................... 55

E. Aplikasi Etika dan Profesionalisme ............................... 55

PERANCANGAN SISTEM PRODUKSI .................................. 57

A. Concurrent Engineering …………....................................... 57

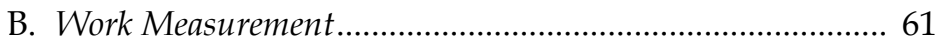

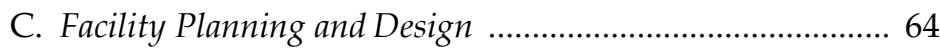

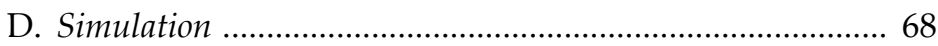

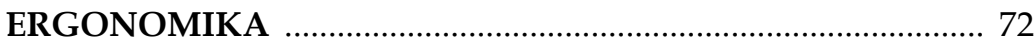

A. Konsep Dasar Ergonomi ………….................................. 72

B. Perancangan Sistem Manusia dan Mesin ....................... 73

PENGENDALIAN SISTEM PRODUKSI ................................... 77

A. Logistik dan Supply Chain Management (SCM) ............... 77

B. Perencaaan dan Pengendalian Produksi.......................... 80

C. Pengendalian Kualitas ........................................................ 81

PENGENDALIAN SISTEM PRODUKSI …………………...... 84

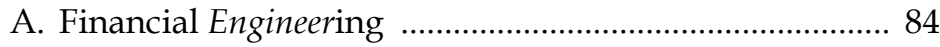

B. Productivity and Operations Research ……………...... 87

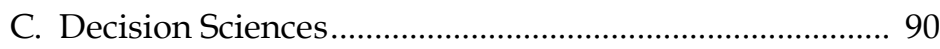

DAFTAR PUSTAKA …………………………………............... 93 


\section{BUKU AJAR \\ PENGANTAR TEKNIK INDUSTRI}




\section{SEJARAH KEILMUAN TEKNIK INDUSTRI}

\section{Tujuan Pembelajaran:}

Mahasiswa mampu mengetahui dan memahami tentang sejarah keilmuan teknik industri

\section{Materi:}

1. Profesi Teknik Industri Lahir

2. Era Perkembangan Teknik Industri

\section{A. Profesi Teknik Industri Lahir}

Profesi Teknik Industri lahir sejak persoalan industri terjadi, sejak manusia harus mewujudkan sesuatu untuk memenuhi keperluan hidup; persoalan produksi muncul pada zaman Pra Yunani Kuno; saat manusia menggunakan batu sebagai peralatan bekerja; alat-alat yang digunakan mengalami perbaikan secara terus menerus dengan cara coba-coba dan manusia melakukan seleksi alat yang sesuai untuk keperluan kerja; perbaikan-perbaikan ini tidak lain hanya untuk meningkatkan produktivitas pada persoalan produksi dan ini terjadi hingga saat ini. Era teknik (Engineering Era) pada awal mulanya (early) dan jaman moderen (modern) tergambar seperti di bawahini.

\section{ENGINEERING ERA}

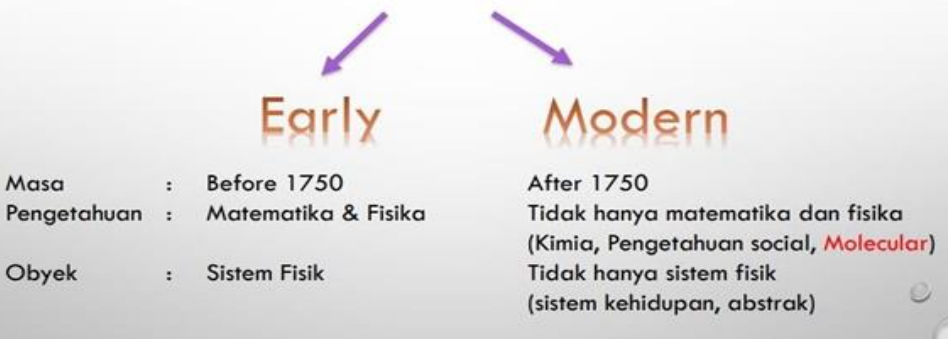

Gambar 1. Engineering Era Early and Modern 
Early Engineering Era terjadi ketika Egyptian Engineering (3200 BC), Mesopotamian Engineering (2000 BC), Greek Engineering (500 BC), Roman Engineering (320 BC), Oriental Engineering dan Europan Engineering. Sedangkan untuk Modern Engineering terbagi menjadi 2 (dua) bagian yaitu sebagai berikut:

a. Big Five Engineering terdiri dari civil, mechanical, electrical, chemical dan industrial engineering.

b. Newer Engineeering terdiri dari nuclear, computer, bioengineering, environmental, dan sebagainya.

Adapun kaitan antara Teknik Industri dengan disiplin Teknik lainnya seperti terlihat pada gambar di bawah ini.

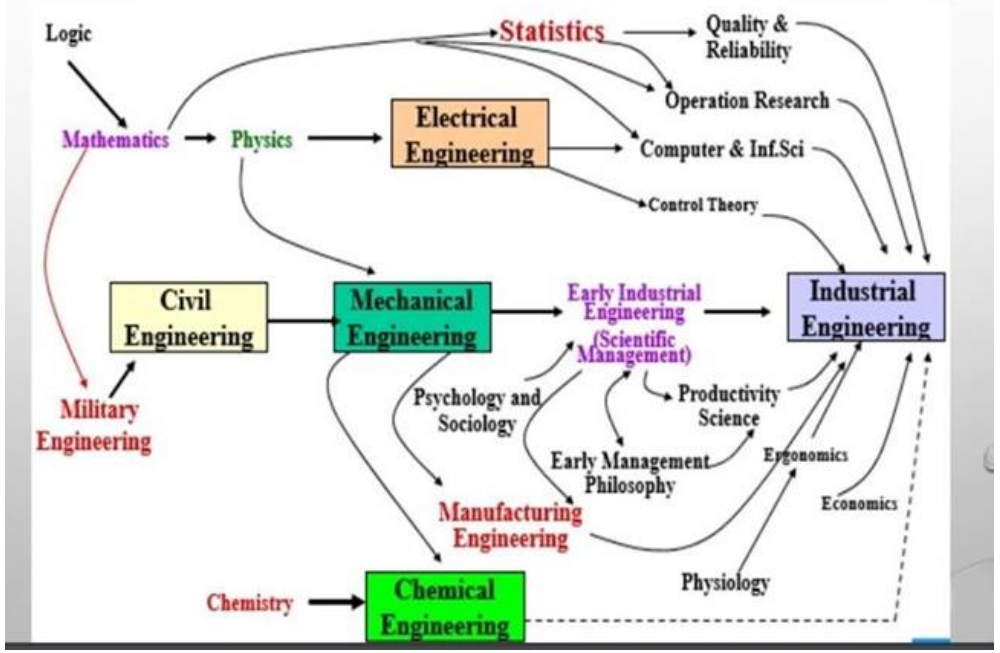

Gambar 2. Kaitan Teknik Industri dengan Teknik lainnya 5 (lima) disiplin Ilmu Teknik Indtri adalah

a. CivilEngineering danMechanical Engineering mathematics + physics $\longrightarrow$ steamengine

b. Electrical Engineering mathematics + physics Telegraph : Samuel Morse Carbon Filament Lamp : Thomas Edison 
c. Chemical Engineering

mathematics + physics + chemistry $\longrightarrow$ synthetic material

d. Industrial Engineering

mathematics + physics + man $\longrightarrow$ integrated system

Kenapa Teknik Industri lahir, alasannya adalah sebagai hasil renovasi industri, kebutuhan untuk melatih orang secara teknik agar bisa menrencanakan, mengatur dan mengelola operasi dari sistem kompleks yang besar serta kebutuhan untuk meningkatkan produktivitas dan efisiensi sistem operasi.

Teknik Industri berkaitan dengan perancangan, perbaikan dan instalasi dari sitem terintegrasi yang terdiri dari manusia, bahan, informasi, pelatan dan energi. Teknik Industri membutuhkan pengetahuan khusus dan keterampilan dalam bidang matematika, fisika dan ilmu sosial yang diterapkan bersama-sama dengan prinsip-prinsip dan metode dari teknik analasis dan perancangan untuk menentukan, memprediksi dan mengevaluasi hasil yang diperoleh daru suatu sistem. Objek perancangan dari Sistem Terintegrasi (Integrated System) terdiri dari manusia (people) ditambah peralatan ditambah material ditambah informasi dan ditambah energi. Kompetensi dari Sistem Terintegrasi (Integrated System) dapat dilihat pada gambar di bawah ini:

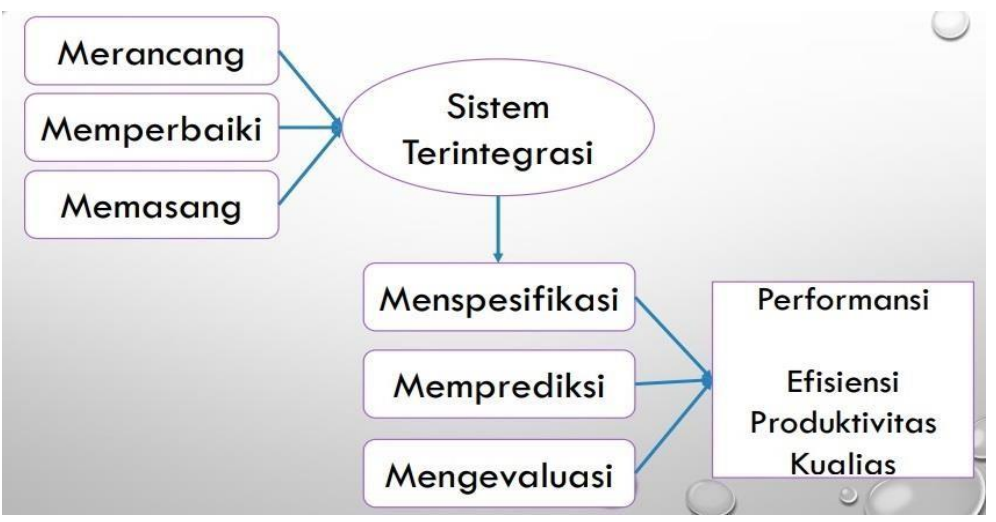

Gambar 3. Kompetensi Sistem Terintegrasi (Integrated System) 
Teknik Industri memiliki ruang lingkup area kerja seperti terlihat di Gambar 4 di bawah ini.

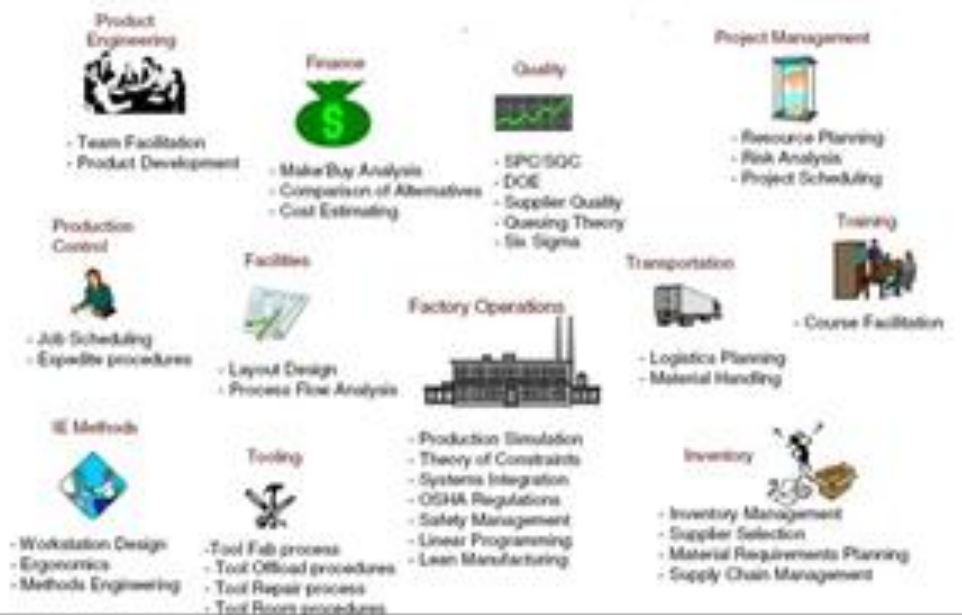

Gambar 4. Ruang Lingkup Area Kerja Teknik Industri

\section{B. Era Perkembangan Teknik Industri}

Kronologi pengembangan evolusi Teknik Industri dimulai pada tahun 1494 hingga tahun 200 an terlihat pada Gambar 5 di bawah ini.

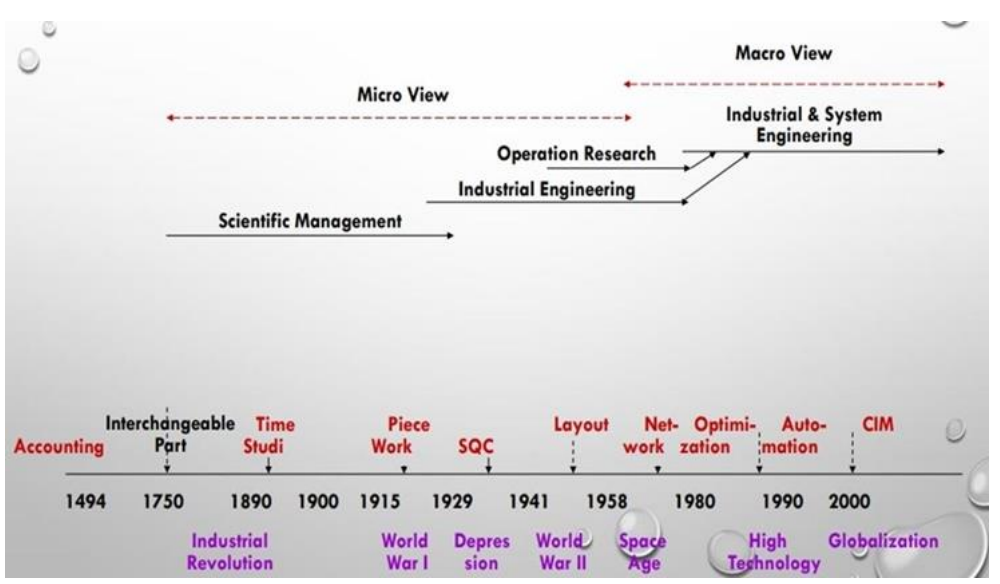

Gambar 5. Evolusi Teknik Industri 
Kemudian diikuti oleh pemikiran Teknik Industri itu sendiri adalah Scientific Management dengan Man-Machine System pada akhir Abad 18, Administration and Behavior Management dengan Human and Organization pada akhir Abad 18, Management Science dengan Optimization and Modelling pada awal Abad 20 dan System and Integrated dengan Integrated System pada pertengahan Abad 20.

Objek dan Keilmuan Teknik Industri terlihat pada Tabel 1 di bawah ini.

Tabel 1. Objek dan Keilmuan Teknik Industri

\begin{tabular}{|c|c|c|c|}
\hline Objek & Komponen & Keilmuan & Kinerja \\
\hline $\begin{array}{l}\text { Stasiun } \\
\text { Kerja }\end{array}$ & $\begin{array}{c}\text { Manusia, Mesin, } \\
\text { Bahan }\end{array}$ & $\begin{array}{c}\text { Ergonomi, } \\
\text { Ekonomi Teknik, } \\
\text { Psikologi Industri }\end{array}$ & $\begin{array}{c}\text { Produktifitas } \\
\text { Efisiensi }\end{array}$ \\
\hline Manufaktur & $\begin{array}{c}\text { Manusia, } \\
\text { Mesin, Bahan }\end{array}$ & $\begin{array}{c}\text { Persediaan, PPC, } \\
\text { Pengendalian } \\
\text { Kualitas, } \\
\text { Perancangan } \\
\text { Tata Letak, } \\
\text { QR dan } \\
\text { Modelling }\end{array}$ & $\begin{array}{c}\text { QCD } \\
\text { (Quality Cost } \\
\text { Delivery) }\end{array}$ \\
\hline Perusahaan & $\begin{array}{l}\text { Tenaga Kerja, } \\
\text { Fasilitas, } \\
\text { Bahan }\end{array}$ & \begin{tabular}{c|} 
Manajemen, \\
Kepemimpinan, \\
Ilmu \\
Perilaku
\end{tabular} & ROI, IRR, ROE \\
\hline $\begin{array}{l}\text { Sistem } \\
\text { Industri }\end{array}$ & $\begin{array}{l}\text { Tenaga Kerja, } \\
\text { Bahan, } \\
\text { Infrastruktur }\end{array}$ & $\begin{array}{l}\text { Kebijakan, } \\
\text { Pendekatan, } \\
\text { Sistem }\end{array}$ & $\begin{array}{c}\text { Kualitas, } \\
\text { Kesejahteraaan }\end{array}$ \\
\hline
\end{tabular}


Perkembangan Teknik Industri sampai Tahun 1950

1. Tokoh-tokoh

a. Adam Smith (17760) : Specialisation, Productivity

b. Charles Babbage (1832) ; Pembagian Kerja

c. Fredrick W. Taylor (1905) : Scientific Management

d. Frank and Lilian Gilberth (1912) : Micro-Motion Study

e. Fayol : The 14 Principle of Management

2. Organisasi
a. Society to promote The Science of Management(1912)
b. The Taylor Society (1915)
c. Society Industrial Engineers (1917)

3. Konsep-Konsep:
a. Welath of Nations : Spesialisasi / Keahlian untuk Produtivitas
b. Economy of Machine and Manufacturers : Pembagiankerja
c. Principles of Science Management
d. Human Factors : Micro-Motion Economy
e. Principle of Management

1. Perkembangan Teknik Industri pada Tahun 1950 sampai 1970

American Institute of Industrial Engineers (AIIE) pada tahun 1948 ada bidang perhatian seperti tektik tata cara; pengukuran kerja; pengendalian yang terdiri dari produksi persediaan, mutu biaya dan anggaran; evaluasi jabatan dan sistem pengupahan yang terdiri dari analisis jabatan, analisis kinerja, upah perangsang dan administrasi pengupahan; serta rancangan dan fasilitas pabrik terdiri dari tata letak, pengadaan dan peremajaan peralatan, perancangan produk, perkakas dan peralatan. Dalam sarana terdri dari statistika, penelitian operasional dan psikologi industri. 


\section{Perkembangan Teknik Industri pada Tahun 1970 sampai 1990}

AIIE menjadi IIE dimana bidang perhatiannya adalah bidang industri yang terdiri dari antariksa, bank dan keungan, industri elektronika, pemerintahan, seni, grafis, pelayanan kesehatan, retail, industri baja, transportasi dan distribusi serta utilitas; bidang sistem manusia dan informasi terdiri dari komputer dan sistem informassi, ekonomi teknik, ergonomi, hubungan kerja dan industri manajemen, pengukuran kerja dan tata cara; bidang sistem produksi yang terdiri dari manajemen energi, perancangan dan perencanaan fasilitas, sistem manufaktur, penelitian operational, pengendalian produksi dan persediaan serta pengendalian mutu dan keandalan.

\section{Perkembangan Sejak 1990}

Topik-topik baru yang timbul adalah Computer Integrated Manufacturing (CIM), Decision Support System (DSS), Just In-Time Process Planning (JIT), perkembangan variassi sistem produksi, penelitian operasional, manajemen sumber daya manusia dan sebagainya, knoeledge-based management dan lain-lain, topik-topik lama tetap berkembang serta Ergonomi dan sebagainya. Perkembangan tahun ini didasari oleh perkembangan komputer dan teknologi informasi.

\section{Proyeksi Perkembangan Abad ke-21}

Proyek perkembangan Abad 21 sangat dipengaruhi oleh teknologi informasi. Hal- hal yang mempengaruhi adalah perubahan pola kerja, gaya hidup dan bentuk transaksi; perubahan gaya kepemimpinandan manajemen; pergeseran pengendalian kekuasaan ekonomi dan politik. Ada juga perubahan pola kerja, gaya hidup dan transaksi yang terdiri dari kerja idividual, outsourching/networking dan modal maya serta internet driven yang terdiri dari e-commerce, e-mail, distance learning dan service. Kepimpimpinan masa 
depan terdiri dari visioner, kreatif, transformamatif, komunikatif, memperdayakan, integratif-networking-sinergis, high-touch and high-tech, antisipatif, adaptif dan kompeten. Pengendali kekuasaan yaitu bergeser dari pimpinan negara ke pimpinan pengendali informasi. 


\section{RUANG LINGKUP KEILMUAN TEKNIK INDUSTRI}

\section{Materi:}

1. Pengertian Teknik (Engineering)

2. Pengertian Science

3. Karakteristik Dasar Engineers

4. Ruang Lingkup Teknik Industri

\section{A. Pengertian Teknik (Engineering)}

Teknik terkait dengan teknologi, Artifak adalah buatan manusia. Teknik digunakan untuk kenyamanan dan kemudahan. Manfaat untuk kehidupan manusia (mankind). Teknologi (Technology) akar kata (Greek) artinya techne berarti art, craft or skills. The practical apllication of knowlede especially in a particular area (Merriam Webster Dictionary, 2008). A capability gien by the practical application of knowledge (Merriam Webster Dictionary, 2008). Yaitu berupa alat, mesin, instrumen yang secarafisik dipakai manusia, bisa juga berupa keterampilan, metode, prosedur yang dipakai manusia untuk melakukan sesuatu.

Engineering berarti menghasilkan devices, systems, process yang merupakan buatan manusia (artificial system), ditujukan untuk suatu manfaat tertentu, berangkat dari suatu kebutuhan tertentu, bersifat relatif dan memanfaatkan bahan dan kekuatan alam. Menurut Merriam-Webster Dictionary, Engineering is the application of science and mathematics by witch the properties of matter and the sources of energy in nature are made useful to people. Menurut Acreditation Board for Engineering Technology (ABET), Engineering is the profession in which a knowledge of mathematical and natural sciences gained by study, experience and practice is applied with judgment to develop ways to utilize, economically, the materials and forces of nature for the benefit of mankind. 


\section{B. Pengertian Science}

Science merupakan objek yang dipelajari alam (angin, panas, tumbuhan, material dan lain-lain). Mengapa Science dipelajari? Karena curisoty atau ingin tahu. Hasil Science berupa hukum dan teori. Sifat Science bersifat muntlak. Karakteristik Science adalah memperbaiki, memperbaharui, menambah pengetahuan kemudian dilakukan penelitian (research) lalu menjadi scientific method dan kembali ke awal. Adapun bentuk Scientific Method terlihat pada Gambar 6 di bawah ini.

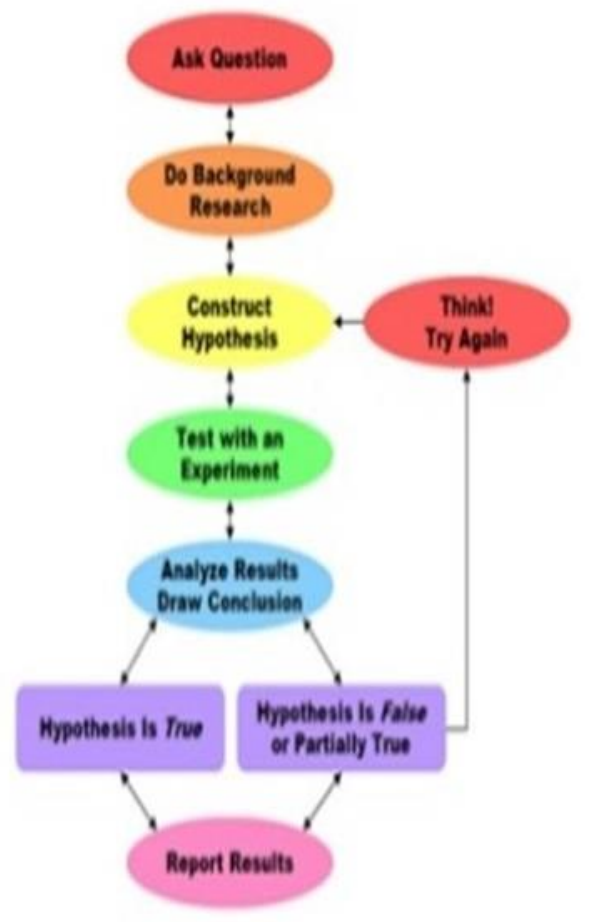

Gambar 6. Scientific Method

Engineering berfungsi untuk menghasilkan alat (device), sistem, proses untuk kepentingan kehidupan manusia kemudia proses perancangan (design). Perancangan menurut ABET adalah engineering design is the process of devising system, component or process to meet desired needs; it is a decision-making process (often iterative), in which the basic science and mathematics and 
engineering sciences are applied to convert resources optimally to meet a stated objective; among the fundamental elements of the design process are the establishment of objectives and criteria, synthesis, analysis, construction, testing and evaluation. Proses perancangan terlihat seperti Gambar 7 di bawah ini.

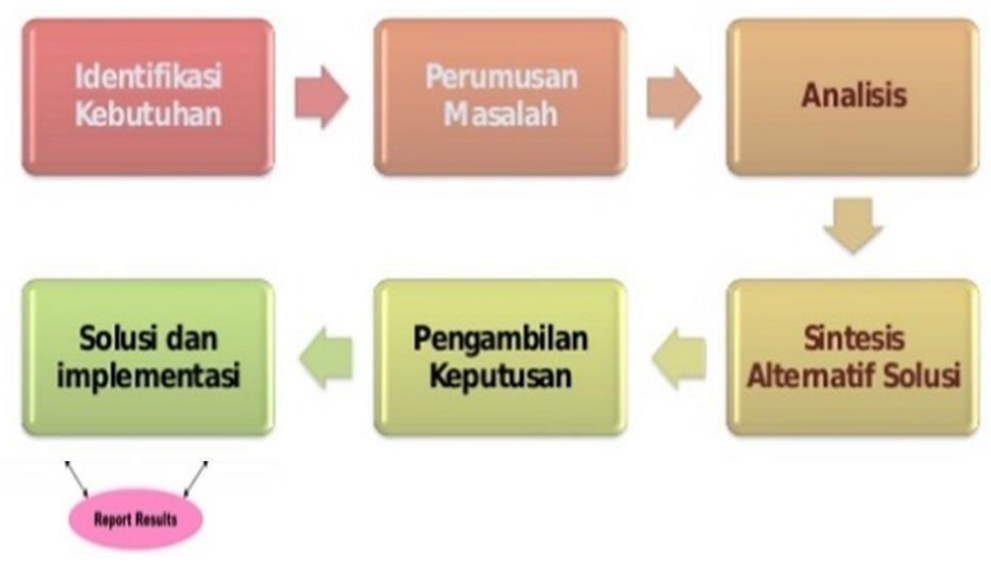

Gambar 7. Proses Perancangan

\section{Karakteristik Dasar Engineer}

Karakteristik dasar engineer adalah memecahkan masalah (problem solver), kemampuan analisis tinggi dan merancang sistem (kreativitas dan analisis-sistesis). Perkembangan teknik dapat terlihat pada Gambar 2. Mengapa Teknik Industri lahir? Karena kelanjutan dari revolusi industri menjadi mass production; dibutuhkan tenaga terampil dalam kemampuan teknis namun bisa mengorganisasikan, merencanakan dan mengelola sistem serta diperlukan untuk mengingkatkan produktivitas dan efisiensi. Definisi Teknik Industri yaitu Industrial Engineering is concerned with th design, improvement and installation of integrated systems of people, material, information, equipment and energy. Model Teknik Industri tergambar pada Gambar 9 di bawah ini. 


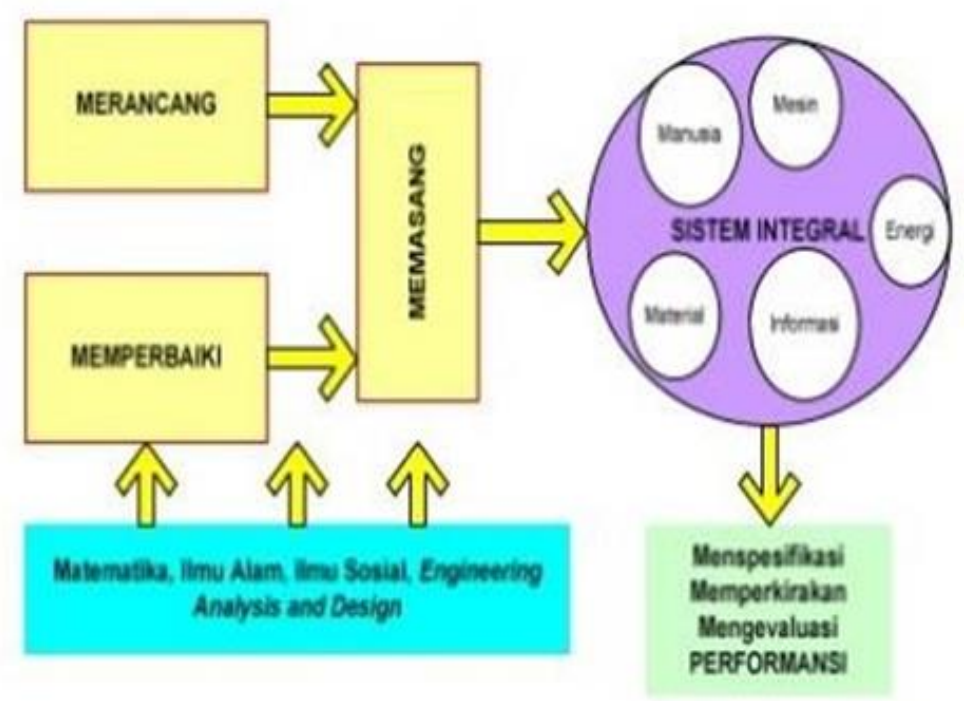

Gambar 9. Model Teknik Industri

Sistem integral tidak selalu berarti pabrik atau industri manufaktur (walaupun asal kelahirannya adalah industri manufaktur). Sistem ingral bisa rumah sakit, bank, universitas dan lain-lain. Sistem terintegral tidak bersifat konkrit, cenderung merupakan proses. Manusia merupakan unsur terpenting di dalamnya yang membuat artifak yang dihasilkan Teknik Industri semakin unik. Ada yang menyebut Sistem Integral ini sebagai socio-techincal system. Ada bagian techical system dan social system. Kalau melihat pabrik atau perusahaan manufaktur maka ada lantai pabrik (techincal system) dan ada organisasi serta manajemen (sosial system). Perbandingan science, engineering dan Industrial Engineering terlihat pada tabel di bawahini. 
Tabel 2. Perbadingan Science, Engineering dan Industrial Engineering

\begin{tabular}{|c|c|c|c|}
\hline & Science & Engineering & Industrial Engineering \\
\hline Basic knowledge & Logic, creativity & $\begin{array}{l}\text { M athematics, } \\
\text { Natural Science }\end{array}$ & $\begin{array}{l}\text { Mathematics, Natural } \\
\text { Science, Social Science }\end{array}$ \\
\hline Tool & Analysis, Sysnthesis & Analysis, Synthesis & $\begin{array}{l}\text { Modelling, M ethod of } \\
\text { engineering analysis }\end{array}$ \\
\hline Process & Scientific Research & $\begin{array}{l}\text { Design, Applied } \\
\text { research }\end{array}$ & $\begin{array}{l}\text { Design, Integrated- } \\
\text { systemic approach }\end{array}$ \\
\hline Output & Theory, Knowledge & Product, Process & Process, Value Added \\
\hline Validity & Absolute & Relative & Contextual \\
\hline
\end{tabular}

Perkembangan Teknik Industri terlihat pada Gambar 9 di bawah ini.

\section{Pekembangan Teknik Industri}

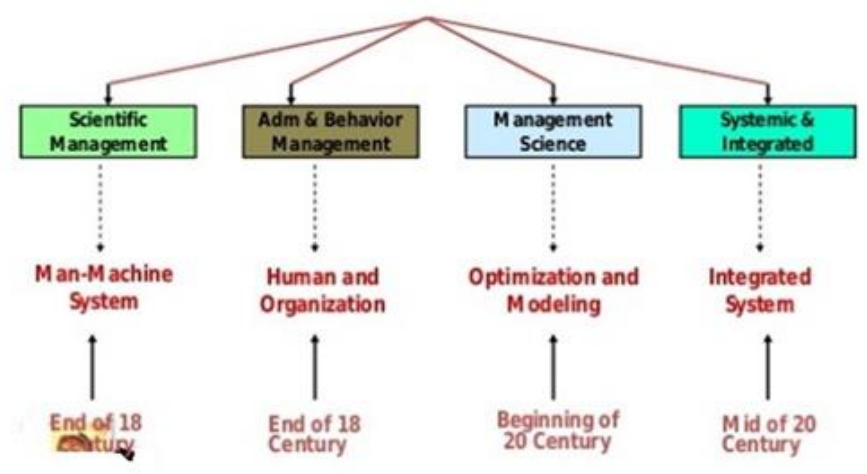

Gambar 10. Perkembangan Teknik Industri

Perspektif level pada sistem terintegrasi Teknik Industri terdiri dari stasiun kerja, lintasan produksi, perusahaan dan supplay chain sector. Contohnya seperti rumah sakit, bank dan lain sebagainya. Objek dan Keilmuan Teknik Industri yang sudah terlihat di Tabel 1 menggambarkan bidang kerja Teknik Industri. Bidang kerja itu diantaranya manager projects, process improvement, supply chain analysis, operations management, integrated system dan direct support to production. Industrial Engineering fuctional work areas terdapat pada Gambar 4. 